\title{
Potential role of endocrine gastrin in the colonic adenoma carcinoma sequence
}

\section{SA Watson*,', TM Morris', DF McWilliams', J Harris', S Evans', A Smith' and PA Clarke'}

'Academic Unit of Cancer Studies, University of Nottingham, Nottingham, NG7 2UH, UK

\begin{abstract}
The role of hyper-gastrinaemia in the incidence of colonic cancer remains to be clarified. The aim of this study was to determine whether cholecystokinin-2 (CCK-2) receptor expression predicts the sensitivity of human colonic adenomas to the proliferative effects of serum hyper-gastrinaemia. Gene expression of the classical $(74 \mathrm{kDa})$ CCK-2 receptor in human colonic adenoma specimens and cell lines, was quantified by real-time PCR. Western blotting, using a CCK-2 receptor antiserum, confirmed protein expression. A transformed human colonic adenoma was grown in SCID mice, with hyper-gastrinaemia induced by protein pump inhibitors. CCK-2 receptor blockade was achieved by using neutralising antiserum. Both human colonic adenoma cell lines and biopsies expressed CCK-2 receptor mRNA at levels comparable with CCK-2 receptor transfected fibroblasts and oxyntic mucosa. Western blotting confirmed immunoreactive CCK-2 receptor bands localised to 45, 74 and $82.5 \mathrm{kDa}$. Omeprazole and lansoprazole-induced hyper-gastrinaemia (resulting in serum gastrin levels of 34.0 and 153.0 PM, respectively) significantly increased the weight of the human adenoma grafts ( $43 \%(P=0.016)$ and $70 \%(P=0.014)$, respectively). The effect of hypergastrinaemia on tumour growth was reversed by use of antiserum directed against the CCK-2 receptor. Hyper-gastrinaemia may promote proliferation of human colonic adenomas that express CCK-2 receptor isoforms. British Journal of Cancer (2002) 87, 567-573. doi:I0.I038/sj.bjc.6600509 www.bjcancer.com
\end{abstract}

(c) 2002 Cancer Research UK

Keywords: gastrin, CCK-2 receptors; colon adenomas; APC Min mouse

Gastrin peptides have been shown to be growth factors for normal colonic epithelial cells (Sobhani et al, 1993; Koh et al, 1997; Renga et al, 1997), as well as those that have undergone malignant transformation (Winsett et al, 1986; Watson et al, 1989). Such findings may be of clinical significance as raised serum gastrin levels may be a common occurrence, being a side effect following either infection with Helicobacter pylori (HP) (Smith et al, 1990; Graham et al, 1991) or administration of proton pump inhibitors (Festen et al, 1986; Lind et al, 1988). The ability of elevated serum gastrin levels to promote colorectal carcinogenesis has been evaluated in a number of chemically induced in vivo models. Omeprazole-induced hypergastrinaemia has consistently failed to increase tumour incidence in carcinogen-induced colorectal malignancy in rats (Penman et al, 1993; Hurwitz et al, 1995; Pinson et al, 1995). Conversely, surgical induction of hyper-gastrinaemia has resulted in an increased incidence of chemically-induced tumours in two studies (McGregor et al, 1982, Karlin et al, 1985). Furthermore, hyper-gastrinaemia decreased survival in the APC ${ }^{M i n}$ mouse model of intestinal polyposis (Watson and Smith, 2001). The reasons for such divergent results are unclear but they highlight the need to examine the risk of hypergastrinaemia in more clinically relevant models.

The majority of epidemiological studies have so far failed to define the true risk of hyper-gastrinaemia as most have not controlled for confounding factors, known to elevate serum gastrin, in the control population (Elsborg and Mosbech, 1979; Brinton et al, 1989; Orbuch et al, 1996). A well-controlled clinical study by

* Correspondence: SA Watson, Academic Unit of Cancer Studies, D Floor, West Block, Queen's Medical Centre, University Hospital, Nottingham, NG7 2UH, UK; E-mail: sue.watson@nottingham.ac.uk

Received 18 February 2002; revised 29 April 2002; accepted 16 May 2002
Thorburn et al (1998) showed that serum hyper-gastrinaemia was associated with a 3.3-fold increase in the relative risk of developing colorectal cancer with $8.9 \%$ of colorectal cancers attributable to increased serum gastrin levels.

The cholecystokinin-B (CCK-2) receptor mediates the physiological effects of gastrin, including growth promoting effects on premalignant and malignant colonic mucosa (Smith and Watson, 2000). Furthermore, gastrin stimulation of CCK-2 receptors expressed by AR42J cells was shown in an in vitro system to reverse apoptosis induced by serum withdrawal through the induction/ activation of protein kinase BAkt (Todisco et al, 2001). A number of isoforms of the CCK-2 receptor have now been discovered (Song et al, 1993; Miyake, 1995; Ohtaki et al, 1996). These include the 'long isoform' which has, due to alternate splicing, an additional five amino acids located within the third intracellular domain (Song et al, 1993; Ohtaki et al, 1996). Use of an alternative first exon, $1 \mathrm{~b}$, which remains untranslated, leads to a receptor truncated at the amino-terminus, known as the $\Delta$ CCK-2. This receptor exists on human colorectal adenocarcinoma specimens and cell lines which have an activated gastrin gene, and therefore has been implicated in mediating the autocrine pathway (McWilliams et al, 1998). More recently, CCK-2 receptors with retained introns 2 and 4 have been described in malignant pancreatic and colorectal cells, respectively (Goetze et al, 2000, Hellmich et al, 2000) with the intron 4 retaining CCK-2 receptor inducing ligand-independent constitutive intra-cellular $\mathrm{Ca}^{2+}$ mobilisation (Hellmich et al, 2000). However their relevance regarding colonic tumour proliferation progression remains to be clarified.

As the classical CCK-2 receptor mediates the proliferative response to endocrine gastrin, the aim of the present study was to define the significance of non-truncated CCK-2 receptor isoforms expressed by human colorectal adenomas. 


\section{MATERIALS AND METHODS}

\section{Human colonic adenoma cell lines}

Three human adenoma cell lines were examined in this study; AA/ $\mathrm{C} 1$ and $\mathrm{RGC} 2 / 42$ are non-tumorigenic adenoma cell lines and $\mathrm{AA} /$ $\mathrm{C} 1 / \mathrm{SB} / 10 \mathrm{C}$ is a semi-transformed variant of $\mathrm{AA} / \mathrm{C} 1$ with limited in vivo tumorigenic potential (Williams et al, 1990). A table of known mutations is shown in Table 1 . These cells were kindly provided by Professor C Parasceva, CRC Laboratories, University of Bristol, UK. The cell lines were maintained at $37^{\circ} \mathrm{C}$ in humidified conditions with $5 \% \mathrm{CO}_{2}$, in conditioned medium from mouse NIH3T3 fibroblasts prepared in DMEM tissue culture medium (GIBCO, Irvine, Scotland) containing 20\% heat-inactivated foetal calf serum (FCS, Sigma, Poole, UK), $2 \mathrm{~mm}$ L-glutamine (Sigma), insulin (0.2 Units $\mathrm{ml}^{-1}$, Sigma) and hydrocortisone $\left(1 \mu \mathrm{g} \mathrm{ml}^{-1}\right.$, Sigma).

The human colorectal adenocarcinoma cells used were LoVo and HT29, both obtained from the ECACC (Porton Down, UK), and the human liver-invasive colorectal adenocarcinoma, $\mathrm{C} 170 \mathrm{HM}_{2}$, established within the Cancer Studies Unit, University of Nottingham, UK (Watson et al, 1993). The CCK-2 receptor transfected NIH3T3 cells were a kind gift from Professor Matsui, Kobe University, Japan, as previously described (Ito et al, 1993). All the above cell lines were maintained in RPMI tissue culture medium supplemented with $10 \%$ FCS and $2 \mathrm{~mm}$ L-glutamine.

\section{Growth in severe combined immuno-deficient (SCID) mice}

$\mathrm{AA} / \mathrm{C} 1 / \mathrm{SB} / 10 \mathrm{C}$ cells were injected subcutaneously (s.c.) into the left flank of mixed sex SCID mice (age 4-5 weeks, bred within the Cancer Studies Unit, University of Nottingham, UK) at a cell concentration of $2 \times 10^{6}$ in $100 \mu \mathrm{l}$. After growth of a palpable tumour (approximately 3 months), tumour tissue was pooled from donor mice and $3 \mathrm{~mm}^{3}$ grafts transplanted s.c. into experimental SCID mice anaesthetised with Hypnorm $\left(0.315 \mathrm{ng} \mathrm{ml}^{-1}\right.$, Jannsen, Belgium) and Hypnovel (5 $\mathrm{ng} \mathrm{ml}^{-1}$, Roche, Switzerland). Tumour grafts were measured as previously described (Watson et al, 1993). One hour before study termination, mice were injected with $10 \mathrm{mg} \mathrm{kg}^{-1}$ bromodeoxyuridine (BrdU) into the peritoneal cavity At the termination of the study, tumour tissue was taken and fixed in formal calcium ( $4 \%$ formaldehyde, $10 \% \mathrm{CaCl}_{2}$ in distilled water) for immunohistological evaluation. Tumour tissue was snap-frozen in liquid $\mathrm{N}_{2}$ for molecular biology studies. UK Co-ordinating Committee for Cancer Research (UKCCCR) Guidelines were adhered to throughout all animal experimentation.

Table I Genetic characterisation of the colonic adenoma cell lines

\begin{tabular}{ll}
\hline Cell line & Characterisation of oncogenic events \\
\hline RGC2 & Full length APC, c-myc but no k-ras mutation \\
AA/CI & Truncated APC, c-myc and k-ras mutation \\
$A A / C I / S B / I O C$ & Truncated APC, c-myc and k-ras mutation \\
\hline
\end{tabular}

\section{In vivo treatment}

Omeprazole (Hospital Pharmacy, Queen's Medical Centre, Nottingham, UK) was administered at a dose of $75 \mathrm{mg} \mathrm{kg}^{-1}$ by gavage as previously described (Watson and Smith, 2001). Lansoprazole (Hospital Pharmacy as above) was prepared in sterile distilled $\mathrm{H}_{2} \mathrm{O}$ and administered orally, daily, in $100 \mu \mathrm{l}$ volumes at a dose of $25 \mathrm{mg} \mathrm{kg}^{-1}$.

Affinity purified polyclonal CCK-2 receptor (gastrin receptor epitope (GRE)-1, Watson et al, 1998) antiserum (Aphton Corporation, CA, USA) was administered at a dose of $100 \mu \mathrm{g}$ protein in a $200 \mu$ l volume, i.v., daily. This antiserum has been shown to inhibit ligand binding and intra-cellular signalling of the CCK-2 receptor (Watson et al, 2000; McWilliams et al, 2001). Protein G purified normal rabbit serum (Aphton, CA, USA), at the same protein concentration, was administered to control mice.

Amidated serum gastrin levels were measured by Professor Andrea Varro (Physiology Department, University of Liverpool) using the L2 antiserum, as previously described (Nemeth et al, 1993).

\section{Measurement of the proliferation index of the adenoma tissue}

Following formalin fixation, specimens were embedded in paraffin, $4 \mu \mathrm{M}$ sections were cut by a microtome and stained with an antibody directed against BrdU as previously described (Watson and Smith, 2001). Nuclei were selected on the basis of colour and were expressed as a percentage of the total adenoma tissue in $n=20$ high power fields. Inter-observer variation was found to be $7.5 \%$ and intra-observer variation $8.8 \%$. Image analysis was performed by the use of the Leica Qwin image processing system (Leica Microsystems, Cambridge, UK).

\section{Human specimens}

Either paraffin-embedded or snap frozen human colonic normal mucosa (from patients without a malignancy), mucosa from the resection margin of patients with an adenocarcinoma and villous adenoma and adenocarcinoma specimens were used for the realtime screen of CCK-2 receptor expression.

For the Western blotting studies, snap frozen tissue was obtained from resection margin mucosa samples, villous adenomas and adenocarcinomas, prospectively. The adenomas were mainly synchronous to adenocarcinomas. Real-time PCR was performed on respective samples, in parallel.

\section{Extraction of RNA}

For frozen and paraffin-embedded tissue, total RNA was extracted as previously described (McWilliams et al, 1998; Smith and Watson, 2000) and reverse transcription performed (McWilliams et al, 1998).

Primer pairs, for use in real time PCR, were designed to amplify only the human classical CCK-2 receptor. The sequences are shown in Table 2.

Table 2 PCR Primer Sequences

\begin{tabular}{lccc}
\hline Primer & Gene & U/L & Sequence \\
\hline GAPU & GAPDH (both species) & $U$ & GGTGAAGGTCGGAGTCAACGGA \\
GAPL & GAPDH (both species) & $\mathrm{L}$ & GAGGGATCTCGCTCCTGGAAGA \\
$\mathrm{HCCl}$ & Human Classical CCK-2 receptor & $U$ & GCCAGACCTGGTCCGTACT \\
$\mathrm{HCC2}$ & Human Classical CCK-2 receptor & $\mathrm{L}$ & TCACTGTCGCCGTCAAAG \\
I4A & Human Intron 4 retained CCK-2 receptor & $U$ & TGGACCACGTGAGCAAAATC \\
I4B & Human Intron 4 retained CCK-2 receptor & $\mathrm{L}$ & TCTCACCCTCACCTTCATTTCA \\
\hline
\end{tabular}




\section{Real Time PCR to quantify CCK-2 receptor expression}

RNA was reverse transcribed from random hexamer primers (Pharmacia) using Superscript RT (GibcoBrl, UK). Real Time PCR was performed using the 5700 Sequence Detection System (PE Applied Biosystems, Warrington, UK). Each PCR was performed according to manufacturer's instructions using $1 \mu \mathrm{l}$ of sample complementary DNA (cDNA) in a $25 \mu \mathrm{l}$ reaction volume. The reaction buffer was prepared from the SYBR Green PCR Core Kit (PE Applied Biosystems) and consisted of $1 \times$ SYBR Green PCR Buffer (PE Applied Biosystems), $3 \mathrm{mM} \mathrm{MgCl}_{2}, 0.2 \mathrm{mM}$ dATP, $0.2 \mathrm{mM}$ dCTP, $0.2 \mathrm{~mm}$ dGTP, 0.4 mm dUTP, 0.25 U AmpErase UNG (PE Applied Biosystems) and $0.625 \mathrm{U}$ Amplitaq Gold (PE Applied Biosystems). The CCK-2 receptor primers and the primers for the house-keeping gene, glyceraldehyde-3-phosphate-dehydrogenase (GAPDH) were included in parallel reactions at a final concentration of $100 \mathrm{nM}$ each. Negative controls were included in which the reverse transcriptase was omitted, to control for genomic DNA contamination.

The fluorescence of the SYBR green dye bound to the CCK-2 receptor and GAPDH PCR products was measured, after each cycle, by the 5700 System and the cycle number was recorded when the accumulated signal crossed an arbitrary cycle threshold $(\mathrm{Ct})$. The relative gene expression for each sample was determined using the formula $2^{\mathrm{ct}(\mathrm{GAPDH})-\mathrm{ct}(\mathrm{CCK}-2)}$ in which CCK-2 receptor gene expression was normalised to GAPDH levels. CCK-2 receptor mRNA levels of the human adenoma xenografts were measured by the ELOCA assay, as previously described (Watson et al, 1999a). Each sample $(n=5)$ was repeated $2-3$ times.

\section{Western blotting}

Western blotting was performed on cell pellets or human tissue, snap frozen in liquid nitrogen, using a rabbit polyclonal antiserum directed against the amino terminus of the classical human CCK-2 receptor, as previously described (Watson et al, 1998).

\section{Statistical analysis}

Results were assessed using the Minitab statistical programme for the PC by the Mann-Whitney $U$ non-parametric test (real time
PCR results) and the in vivo data by Student's $t$-test or one-way analysis of variance.

\section{RESULTS}

Real time CCK-2 receptor profile of colonic adenoma and adenocarcinoma cell lines

The mean $\Delta \Delta \mathrm{Ct}$ (relative gene expression of CCK-2 receptor normalised to GAPDH) of each cell line examined (means of 2-3 repeat PCR reactions performed on two separate cDNA preparations) is shown in Figure 1. The positive control cells used were NIH3T3s transfected with the human classical CCK-2 receptor and the negative control was the human fibroblast cell line BRIG1, which showed no receptor expression at the detection sensitivity of the real time PCR assay ( $\Delta \Delta \mathrm{Ct}<1 \times 10^{-12}$ in five repeated assays, results not shown).

The three human adenoma cell lines expressed classical CCK-2 receptor mRNA. The $\Delta \Delta$ Ct levels of CCK-2 receptor mRNA in the two non-transformed adenoma cell lines were significantly greater when compared to the transformed adenoma, $\mathrm{AA} / \mathrm{C} 1 / 5 \mathrm{~B} /$ 10C $(P=0.0014, \mathrm{AA} / \mathrm{C} 1$ and $P=0.0081, \mathrm{RGC} 2 / 42$, Mann - Whitney). The $\Delta \Delta \mathrm{Ct}$ levels for the receptor were also higher in $\mathrm{AA} / \mathrm{C} 1$ and RGC2/42 cells when compared to the adenocarcinoma cell lines $(P=0.0008, P=0.0032$ respectively). However, CCK-2 receptor $\Delta \Delta \mathrm{Ct}$ levels of the two non-transformed adenomas were not significantly different from those expressed by the NIH3T3 CCK-2 receptor transfectants and were lower than the levels expressed by oxyntic mucosa $(P=0.0108$, for $\mathrm{AA} / \mathrm{C} 1$ and $P=0.0081$ for RGC2/42). When comparing the adenocarcinoma cell lines, there was no significant difference in $\Delta \Delta \mathrm{Ct}$ for the classical CCK-2 receptor between all three lines, however, the $\Delta \Delta \mathrm{Ct}$ values were lower than the level expressed by the NIH3T3 receptor transfectant $(P=0.0107)$, and oxyntic mucosa $(P=0.001)$.

\section{Real time CCK-2 receptor profile of human colonic normal mucosa, adenoma and adenocarcinoma specimens}

As real-time quantification was to be performed, mRNA extracted from surgically resected specimens was assessed for high integrity by careful analysis of house-keeping gene expression. Maximal
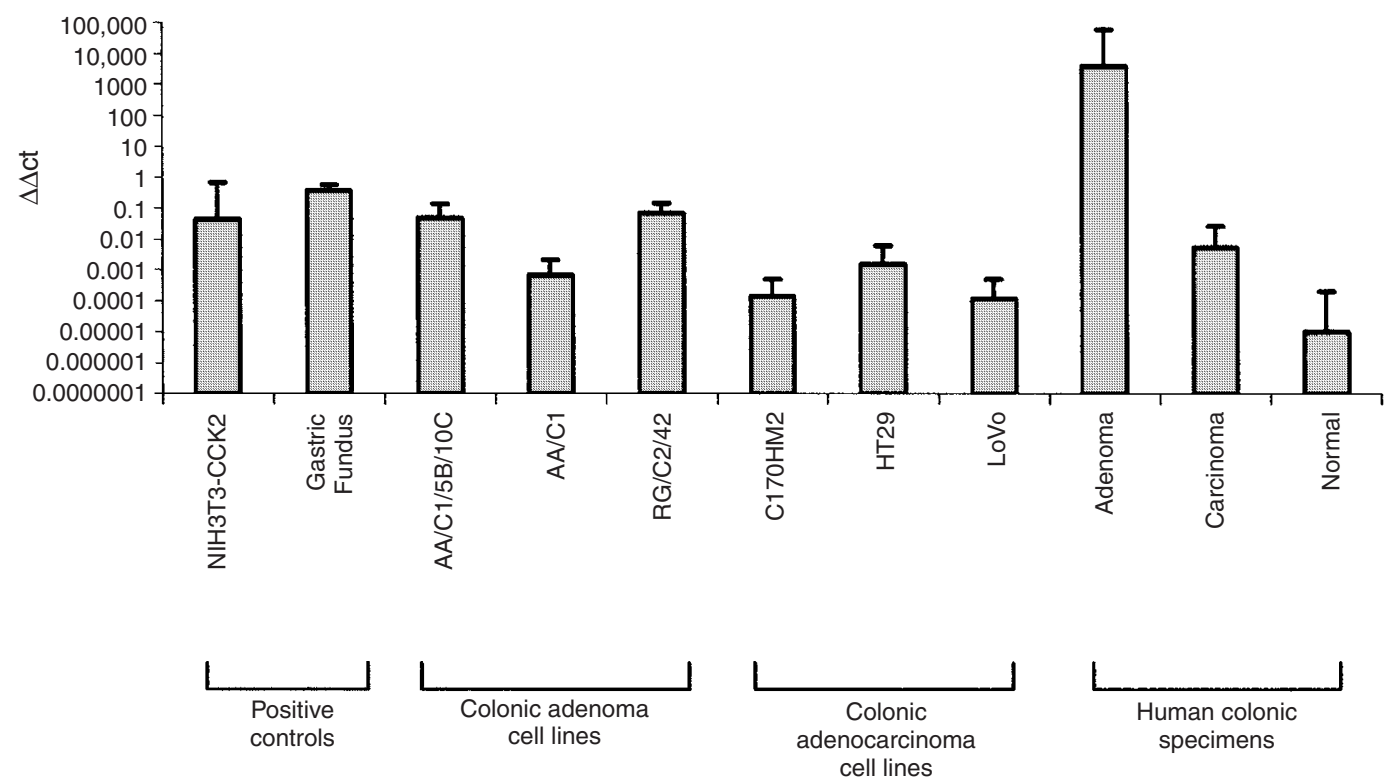

Figure I Gene expression of CCK-2 wild type $(74 \mathrm{kDa})$ receptors in a panel of colonic adenoma and adenocarcinoma specimens and cell lines as determined by real time PCR. Mean expression of 2 to 3 separate PCR reactions per sample are shown together with the standard deviations of the mean. 
expression of a panel of house-keeping genes (glyceraldehyde phosphate dehydrogenase (GAPDH), Glycerol-3-phosphate dehydrogenase (G3PDH), $\beta$-actin, 18S RNA) has previously been validated by the use of human colonic tissue samples immediately snapfrozen at endoscopy (D McWilliams, personal communication). Only samples with the correct house-keeping mRNA profile were used, resulting in limited numbers for the final assessments, as follows: (i) non-malignant colonic mucosa $(n=5)$, (ii) resection margin mucosa from patients with a colonic adenocarcinoma $(n=12)$, (iii) villous adenomas $(n=11)$, and (i.v.) colonic adenocarcinomas $(n=13)$. The adenoma specimens expressed greater CCK-2 receptor $\Delta \Delta$ Cts than the adenocarcinomas $(P<0.0001$, MannWhitney), resection margin normal mucosa $(P=0.0003)$, NIH3T3 CCK-2 receptor transfectants $(P=0.005)$ and oxyntic mucosa $(P=0.0001)$. The adenocarcinomas expressed lower CCK-2 receptor $\Delta \Delta$ Ct levels than oxyntic mucosa $(P=0.0001)$ and NIH3T3 CCK-2 receptor transfectants $(P=0.018)$, but higher levels than resection margin mucosa $(P=0.0063)$. Normal colonic mucosa taken from patients without a malignancy showed no receptor expression at the detection level of the real time PCR assay $\left(\Delta \Delta \mathrm{Ct}<1 \times 10^{-12}\right.$ for all samples examined, data not shown).

\section{Western blot analysis of CCK-2 receptor expression of human adenoma cell lines and colonic normal resection margin mucosa, adenoma and adenocarcinoma specimens}

Using the GRE1 antiserum, an immunoreactive band at the $74 \mathrm{kDa}$ molecular weight was expressed by the human adenoma cell lines (Figure 2A) and the human colonic adenoma specimens (Figure 2B shows a panel of representative specimens from a series of eight so far examined), together with normal resection margin colonic mucosa and in one example, a synchronous adenocarcinoma. A specific immunoreactive band was also shown at $45 \mathrm{kDa}$. The $66 \mathrm{kDa}$ band was non-specific as it was also expressed in the negative control blots (epitope adsorbed antiserum).

The human colonic adenocarcinomas (a representative panel from a series of $>30$ screened) all expressed an immunoreactive doublet at both 74 and $82 \mathrm{kDa}$ following staining with the GRE1 antiserum (Figure 2C). No $45 \mathrm{kDa}$ band was present. The resection margin normal mucosa expressed weaker bands, the doublet being evident in 1 out of 3 samples shown and $74 \mathrm{kDa}$ bond expressed exclusively in 1 out of 3 . The GRE1 Western blot profiles of the colon adenocarcinoma cell lines have previously been published (Watson et al, 1998). Real-time PCR confirmed gene expression of the CCK-2 receptor in selected samples (data not shown).

\section{In vivo effect of hyper-gastrinaemia on the growth of $\mathrm{AA} / \mathrm{C} 1 / \mathrm{SB} / 10 \mathrm{C}$}

The mean serum amidated gastrin levels in the vehicle treated mice ( $n=7 / 8$ replicates/group) was $14.0 \mathrm{pM}$ (standard deviation of 2.4) compared to $34.0 \mathrm{pM}$ in the omeprazole treated mice (standard deviation of 10.3).

The terminal mean tumour cross-sectional areas and weights from two separate studies are shown in Table 3. Omeprazole induced a $28 \%$ increase in tumour area $(P=0.005$, Student's $t$-test $)$ and a $43 \%$ increase in tumour weight $(P=0.016)$. The BrdU labelling index of tumours treated with omeprazole was assessed in the first study only and there was a 1.3 -fold increase over vehicle treated controls $(P=0.045)$.

\section{CCK-2 receptor mRNA expression in the adenoma xenografts}

CCK-2 receptor mRNA was measured in adenoma xenografts from both vehicle control and omeprazole treated mice (Table 4). There was a 13-fold elevation in the CCK-2 receptor: GAPDH ratio in omeprazole treated tumours ( $P=0.0122$, Mann - Whitney).
Table 3 Effect of omeprazole-induced hyper-gastrinaemia on the in vivo growth of the human transformed colonic adenoma $\mathrm{AA} / \mathrm{CI} / \mathrm{IOB} / \mathrm{SC}$ as assessed by tumour cross-sectional area, tumour weight measurement and labelling index

\begin{tabular}{|c|c|c|c|}
\hline $\begin{array}{l}\text { Group } \\
\text { ( } n=15 \\
\text { mice/group) }\end{array}$ & $\begin{array}{l}\text { Mean tumour } \\
\text { cross-sectional } \\
\text { area }\left(\mathrm{mm}^{2}\right)\end{array}$ & $\begin{array}{c}\text { Mean tumour } \\
\text { weight (g) }\end{array}$ & $\begin{array}{l}\text { Labelling index } \\
\text { \%BrdU +ve } \\
\text { nuclei/total tissue } \\
\text { area }\end{array}$ \\
\hline Vehicle & $128.15(38.55)$ & $0.37(0.12)$ & $7.1(0.6)$ \\
\hline Omeprazole & $164.15(44.47)$ & $0.53(0.15)$ & $9.3(1.9)$ \\
\hline Two separate studies ${ }^{a}$ & $P=0.005^{\mathrm{a}}$ & $P=0.016^{a}$ & $\begin{array}{c}P=0.045 \\
\text { (I st study only) }\end{array}$ \\
\hline
\end{tabular}

aSignificantly increased when compared to the vehicle control, Student's $t$-test (Standard deviations are shown in brackets).

Table 4 Effect of omeprazole treatment on the CCK-2 receptor: GAPDH mRNA expression of $\mathrm{AA} / \mathrm{Cl} / 5 \mathrm{~B} / \mathrm{IOC}$ xenografts

\begin{tabular}{lc}
\hline Treatment group & $\begin{array}{c}\text { CCK-2 receptor: GAPDH ratio } \\
\text { Median }\end{array}$ \\
\hline Veh\% confidence interval)
\end{tabular}

${ }^{a} P=0.0$ I 22, Mann - Whitney.

\section{Western blotting of the adenoma xenografts}

Western blotting was performed on four xenografts from each experimental group. Each sample was a pool of two xenografts and each was loaded onto the gel at an equivalent protein concentration. The results are shown in Figure 3. There was specific immunoreactivity at $74,82.5$ and $120 \mathrm{kDa}$ (blot shown in Figure $3 a)$. The latter two bands were only visible in adenomas treated with omeprazole. Densitometry scans were generated from the Western blots and the specific bands are shown in Figure $3 \mathrm{~b}$. The scans highlight the increase in density of the 74 and $82.5 \mathrm{kDa}$ doublet in adenomas from omeprazole treated mice and the novel expression of higher molecular weight immunoreactivity at $120 \mathrm{kDa}$.

\section{Reversal by blockade of the CCK-2 receptor}

To confirm that the in vivo growth effect was directly related to serum hypergastrinaemia, lansoprazole was used to generate both greater increases in serum gastrin (mean of 153.0, s.d. of 49.0 pM) and to dissociate any molecule-specific effects of omeprazole. GRE1 antiserum was co-administered to reverse the growth effects by receptor blockade. Figure 4 shows that lansoprazole increased the final mean tumour weight by $70 \%(P=0.014$, one way analysis of variance). This was reversed by co-administration of GRE1 antiserum such that it was non-significant from the vehicle control ( $P=0.148$ when compared to the vehicle control; $P=0.001$ when compared to lansoprazole + normal rabbit serum). GRE1 antiserum alone, significantly reduced basal growth by $38 \%$ $(P=0.014)$.

\section{Intron IV CCK-2 receptor gene expression by the $\mathrm{AA} / \mathrm{C1} / \mathrm{SB} / 10 \mathrm{C}$ adenoma cell line}

Real time PCR on the above cell line confirmed gene expression of the CCK-2 receptor retaining intron IV. The mean $\Delta \Delta \mathrm{Ct}$ of two separate cDNA samples performed twice was 0.021 (standard deviation of 0.014 ) indicating positive expression. 
A
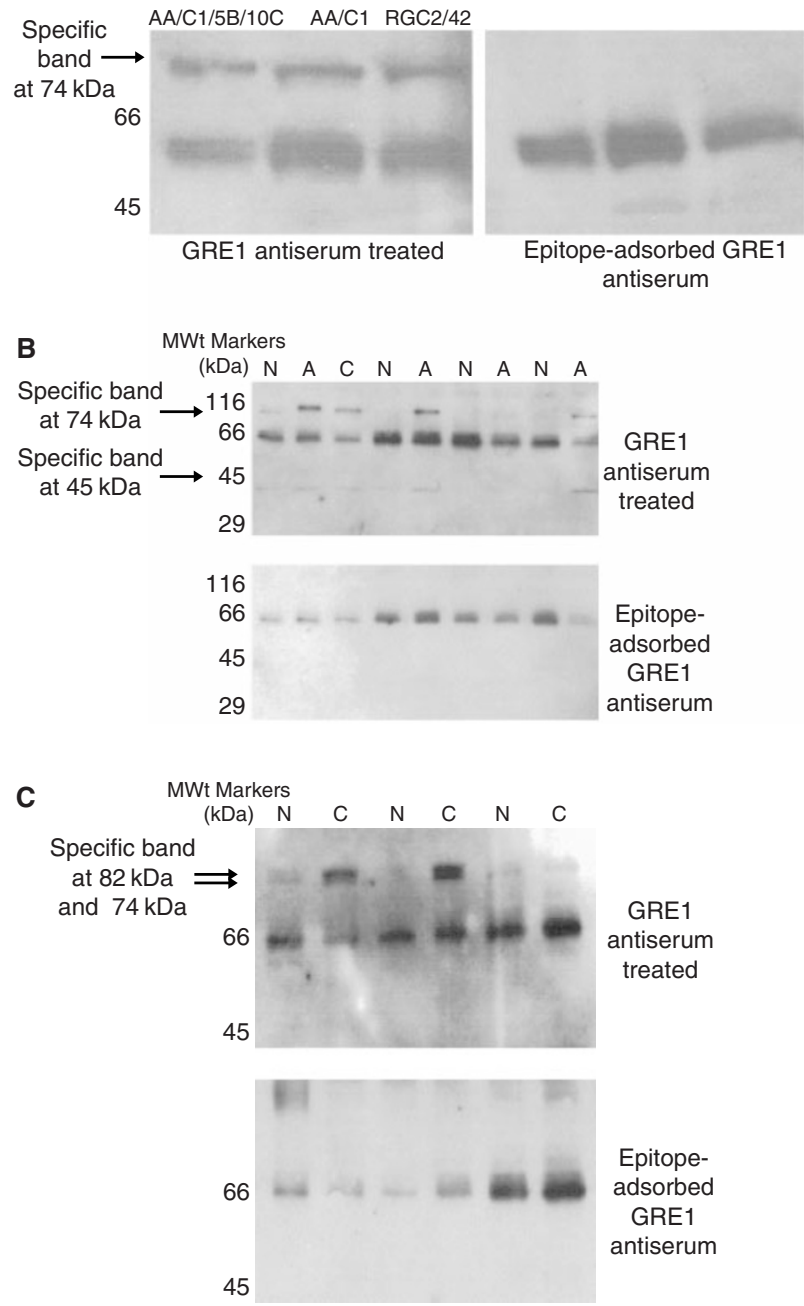

Figure 2 Western blot analysis showing CCK-2 receptor isoform immuno-reactivity of human colonic adenoma specimens and human colonic adenoma cell lines. (A) Human colonic adenoma cell lines. (B) Human colonic adenoma specimens. Resection margin normal $(\mathrm{N})$, adenoma $(\mathrm{A})$ and adenocarcinoma (C) specimens from individual patients. (C) Human colonic adenocarcinoma specimens. Resection margin normal $(N)$ and adenocarcinoma (C) specimens from individual patients.

\section{DISCUSSION}

Serum hypergastrinaemia has become a more common occurrence in recent years, partly as a result of an increase in the use of proton pump inhibitors for acid secretory disorders (Festen et al, 1986; Lind et al, 1988). Furthermore, a positive temporal relationship has been observed between hyper-gastrinaemia and increased incidence of colon cancer with $8.9 \%$ of colon cancer being shown to be attributable to elevated gastrin levels (Thorburn et al, 1998), indicating a sub-group of patients exhibiting increased sensitivity.

Recent publications have indicated that for serum hyper-gastrinaemia to impact upon tumour progression there needs to be coexpression of CCK-2 receptors. In transgenic mouse models of hypergastrinaemia, gastrin induces CCK-2 receptor expression in gastric pit cell precursors (Nakajima et al, 2002) and invasive gastric carcinoma (Wang and Dockray, 1999). To induce pancreatic carcinomas, the hyper-gastrinaemic hGAS transgenic mouse model was crossed with the ELAS CCK-2 receptor mouse which

\section{A}

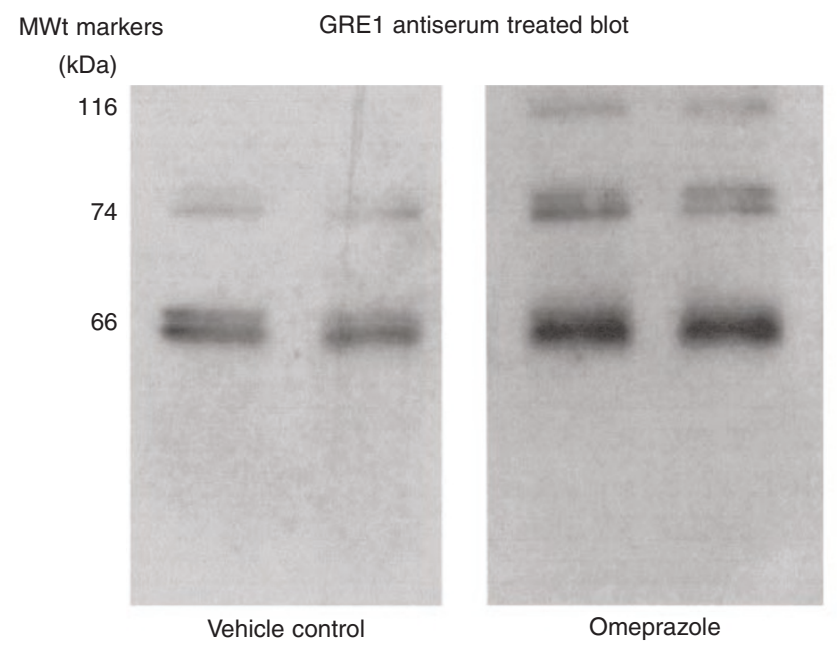

B

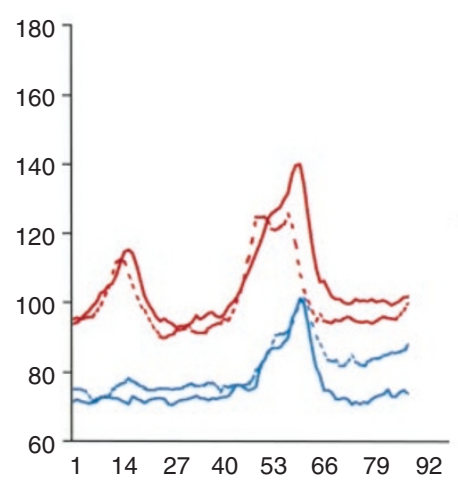

Figure 3 Western blot analysis showing CCK-2 receptor immuno-reactivity of human colonic adenoma xenografts. (A) Western blots ( \pm omeprazole treatment). (B) Densitometry scans of the immunoreactive bands generated from the Western blots. Red line: imunoreactive bands from grafts obtained from omeprazole-treated mice. Blue line: immunoreactive bands from grafts obtained from vehicle-treated mice.

over-expresses CCK-2 receptors in the pancreas. In $13 \%$ of the hybrid mice, carcinoma of the pancreas was present by 18 months (Clerc et al, 2002).

Studies determining the effect of hyper-gastrinaemia on premalignant polyps in the human colon have been limited despite it being shown that CCK-2 receptors are expressed by human adenomas (Smith and Watson, 2000). The incidence of colonic polyps was reported to be increased in patients with Helicobacter pylori infection (Breuer-Katschinski et al, 1999) but any relationship between serum hyper-gastrinaemia and adenoma/polyp proliferation remains tenuous. In the present study, maximal expression of classical CCK-2 receptor gene was shown in both human colonic adenoma cell lines and human adenoma specimens when compared to colonic adenocarcinomas. This is the first study to indicate that the proliferative effects of serum hyper-gastrinaemia on tumour progression may have maximum impact during the adenoma stage. It may also explain the sensitivity of the $\mathrm{APC}^{\mathrm{Min}}$ mouse to elevated gastrin levels, which resulted in decreased survival (Watson and Smith, 2001). The $8.9 \%$ colorectal cancers arising from serum hyper-gastrinaemia may therefore represent a population of patients with pre-existing colonic polyps. 


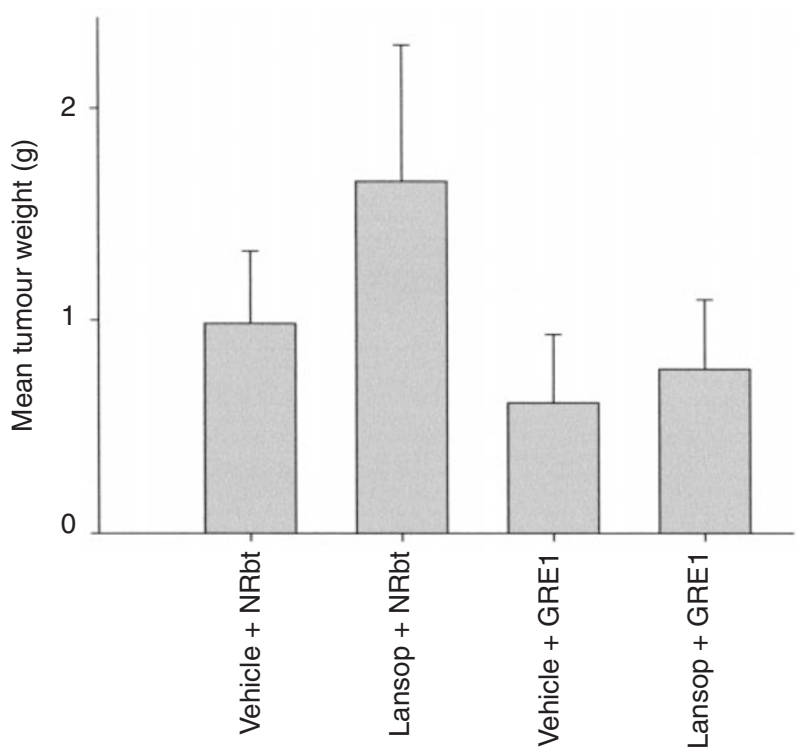

Figure 4 Final adenoma weights of mice treated with lansoprazole to generate hyper-gastrinaemia and co-administered with a polyclonal affinity purified antiserum, GREI, directed against the CCK-2 receptor. Group I: Oral vehicle (phosphate buffered saline (PBS), pH 7.2) + Protein A purified normal rabbit serum ( $n=1 \mid$ mice). Group 2: Lansoprazole (orally dosed daily, $0.75 \mathrm{mg} / \mathrm{mouse}$ ) + normal rabbit serum ( $n=10$ mice). Group 3: Oral vehicle + GREI antiserum ( $n=12$ mice). Group 4: Lansoprazole + GREI antiserum ( $n=||$ mice).

The reason for the lower gene expression of the classical CCK-2 receptor at the adenocarcinoma stage is unknown. At the protein level we have previously shown that the intron IV retained CCK2 receptor splice variant may be the predominant form expressed by colonic adenocarcinomas (Clarke et al, 1999; 2001). In the present study, an $82 \mathrm{kDa}$ immuno-reactive band was co-expressed with the $74 \mathrm{kDa}$ band (relating to the molecular weight of the classical CCK-2 receptor) following Western blotting with a CCK-2 receptor antiserum in a series of human colonic adenocarcinomas. The larger molecular weight isoform of the CCK-2 receptor was absent from a panel of human adenomas. The $82 \mathrm{kDa}$ band relates (in terms of molecular weight) to the intron IV CCK-2 receptor isoform that would be detected by the antiserum as it is directed against the amino-terminal domain common to both CCK-2 receptor isoforms.

\section{REFERENCES}

Breuer-Katschinski B, Nemes K, Marr A, Rump B, Leiendecker B, Breuer N, Goebell H (1999) Colorectal Adenoma Study Group. Helicobacter pylori and the risk of colonic adenomas. Digestion 60: 210-215

Brinton LA, Gridley G, Hrubec Z, Hoover R, Fraumeni Jr JF (1989) Cancer risk following pernicious anaemia. Br J Cancer 59(5): 810-813

Clarke PA, Grimes S, McWilliams DF, Kleie WV, Khan K, Michaeli D, Caplin M, Watson SA (2001) Antibodies directed against retained Intron 4 of the constitutively active CCK-2 receptor bind to a tumour-specific epitope. Gastroenterol 120: 2526

Clarke PA, Watson SA (1999) Expression of CCKB/Gastrin receptor isoforms in human gastro-intestinal tissue. Digestion 60: P-40

Clerc P, Leung-Theung-Long S, Wang TC, Dockray GJ, Bouisson M, Delisle MB, Vaysse N, Pradayrol L, Fourmy D, Dufresne M (2002) Expression of CCK2 receptors in the murine pancreas: proliferation, transdifferentiation of acinar cells, and neoplasia. Gastroenterol 122(2): $428-437$
The primers used in the real time PCR method were designed for optimal detection of classical CCK-2 receptor and would detect the intron IV containing receptor much less efficiently. Thus, the variations in CCK-2 receptor gene expression between adenomas and adenocarcinomas could reflect a shift to greater expression of intron IV retained CCK-2 receptor isoforms in adenocarcinomas.

Alternatively, it is known that gastrin gene expression is greater in colonic adenocarcinomas than in adenomas (Watson et al, $1999 \mathrm{~b}$ ) and in a series of GI cell lines transfected to over-express the gastrin gene, there was down-regulation of gene and protein expression of classical CCK-2, but not Intron IV CCK-2, receptor isoforms (S Evans, personal communication). Therefore, increased gastrin gene expression could be partly responsible for the downregulation in CCK-2 receptor gene expression seen in the adenocarcinomas. Expression of CCK-2 receptors by human colonic adenomas suggests that the cells may be responsive to serum hyper-gastrinaemia. The CCK-2 receptors expressed by $\mathrm{AA} / \mathrm{C} 1 /$ $1 \mathrm{~B} / 5 \mathrm{~B}$ were shown to be functional, as following in vivo growth, the receptors were up-regulated at both the gene and protein level and mediated a growth response to increased serum gastrin levels induced by administration of protein pump inhibitors. The significant but modest increase in BrdU uptake in omeprazole treated mice may reflect the poorly vascularised status of the subcutaneous grafts at the end-stage of the study. Tumour growth in the lansoprazole treated mice was greater than in the omeprazole treated mice, which may relate to the higher serum gastrin levels, and was completely reversed by co-administration of antiserum blockading the CCK-2 receptor, confirming the growth effect as gastrin-specific.

Interestingly, following growth in hyper-gastrinaemic mice, de novo expression of the $82 \mathrm{kDa}$ form of the CCK-2 receptor was confirmed in AA/C1/SB/10C grafts. This may indicate a shift to a more malignant phenotype in the present adenoma model following exposure to gastrin. Furthermore, a CCK-2 receptor isoform of molecular weight $120 \mathrm{kDa}$ was exclusively expressed in adenoma grafts from hyper-gastrinaemic mice, the structure/function of which has so far not been described.

Thus further clinical studies are warranted to examine the proliferation of polyps from patients with elevated levels of serum gastrin. It may be that the $8.9 \%$ of total colorectal cancers that are attributable to serum gastrin levels may arise in patients with undiagnosed colonic polyps, due to the increased expression of CCK-2 receptors on these pre-malignant lesions. Carefully controlled epidemiological studies are necessary to relate hypergastrinaemia to the incidence of colorectal cancer, considering the widespread use of protein pump inhibitors.

Elsborg L, Mosbech J (1979) Pernicious anaemia as a risk factor in gastric cancer. Acta Med Scand 206(4): 315-318

Festen HP, Tuynman HA, Defize J, Pals G, Frants RR, Straub JP, Meuwissen SG (1986) Effect of single and repeated doses of oral omeprazole on gastric acid and pepsin secretion and fasting serum gastrin and serum pepsinogen 1 levels. Dig Dis Sci 31(6): $561-566$

Goetze JP, Nielsen FC, Burcharth F, Rehfeld JF (2000) Closing the gastrin loop in pancreatic carcinoma. Cancer 88(11): 2487-2494

Graham DY, Opekun A, Lew GM, Klein PD, Walsh JH (1991) Helicobacter pylori-associated exaggerated gastrin release in duodenal ulcer patients. The effect of bombesin infusion and urea ingestion. Gastroenterol 100(6): $1571-1575$

Hellmich MR, Rui XL, Hellmich HL, Fleming RY, Evers BM, Townsend Jr CM (2000) Human colorectal cancers express a constitutively active cholecystokinin-B/Gastrin receptor cell growth. I Biol Chem 275(41): 3212232128 
Hurwitz A, Sztern MI, Looney GA, Pinson DM, Bauer KD, Kimler BF (1995) Effects of omeprazole on cell kinetics of carcinogen-induced colon tumours in rats. Cell Prolif 28(10): 525-531

Ito M, Matsui T, Taniguchi T, Tsukamoto T, Murayama T, Arima N, Nakata H, Chiba T, Chihara K (1993) Functional characterisation of a human brain cholecystokinin-B receptor: a trophic effect of cholecystokinin and gastrin. J Biol Chem 268: 18300-18305

Karlin DA, McBath M, Jones RD, Elwyn KE, Romsdahl MM (1985) Hypergastrinemia and colorectal carcinogenesis in the rat. Cancer Lett 29(1): $73-78$

Koh T, Goldenring J, Ito S, Mashimo H, Kopin AS, Varro A, Dockray GJ, Wang TC (1997) Gastrin deficiency results in altered gastric differentiation and decreased colonic proliferation in mice. Gastroenterol 113: 1015-1025

Lind T, Cederberg C, Forssell H, Olausson M, Olbe L (1988) Relationship between reduction of gastric acid secretion and plasma gastrin concentration during omeprazole treatment. Scan J Gastroenterol 23(10): 1259-1266

McGregor DB, Jones RD, Karlin DA, Romsdahl MM (1982) Trophic effects of gastrin on colorectal neoplasms in the rat. Ann Surg 195(2): 219-223

McWilliams DF, Grimes S, Watson SA (2001) Antibodies raised against the extracellular tail of the $\mathrm{CCKB} /$ gastrin receptor inhibit gastrin-stimulated signalling. Regul Pept 99: 157-161

McWilliams DF, Watson SA, Crosbee DM, Michaeli D, Seth R (1998) Coexpression of gastrin and gastrin receptors (CCK-B and Delta CCK-B) in gastrointestinal tumour cell lines. Gut 42(6): 795-798

Miyake A (1995) A truncated isoform of human CCK-B/gastrin receptor generated by alternative usage of a novel exon. Biochem Biophys Res Commun 208(1): 230-237

Nakajima T, Konda Y, Izumi Y, Kanai M, Hayashi N, Chiba T, Takeuchi T (2002) Gastrin stimulates the growth of gastric pit cell precursors by inducing its own receptors. Am J Physiol Gastrointest Liver Physiol 282: G359G366

Nemeth J, Taylor B, Pauwels S, Varro A, Dockray GJ (1993) Identification of progastrin derived peptides in colorectal carcinoma extracts. Gut 34(1): $90-95$

Ohtaki T, Park I, Song I, Guo Y, Hoeltzel M, Post L, DelValle J, Yamada T (1996) Short and long isoforms of the human CCKB receptor couple to post receptor signalling in a differential manner. Gastroenterol 110(4): A1104

Orbuch M, Venzon DJ, Lubensky IA, Weber HC, Gibril F, Jensen RT (1996) Prolonged hypergastrinaemia does not increase the frequency of colonic neoplasia in patients with Zollinger-Ellison syndrome. Dig Dis Sci 41(3): $604-613$

Penman ID, el-Omar E, McGregor JR, Hillan KJ, O’Dwyer PJ, McColl KE (1993) Omeprazole inhibitors colorectal carcinogenesis induced by azoxymethane in rats. Gut 34(11): 1559- 1565

Pinson DM, Havu N, Sztern MI, Mattsson H, Looney GA, Kimler BF, Hurwitz A (1995) Drug-induced hypergastrinemia: absence of trophic effects on colonic carcinoma in rats. Gastroenterol 108(4): $1068-1074$

Renga M, Brandi G, Paganelli G, Calabrese C, Papa S, Tosti A, Tomassetti P, Miglioli M, Biasco G (1997) Rectal cell proliferation and colon cancer risk in patients with hypergastrinaemia. Gut 41: 330-332
Smith AM, Watson SA (2000) Gastrin and gastrin receptor activation - an early event in the adenoma-carcinoma sequence. Gut 47: 820-824

Smith JT, Pounder RE, Nwokolo CU, Lanzon-Miller S, Evans DG, Graham DY, Evans Jr DJ (1990) Inappropriate hypergastrinaemia in symptomatic healthy subjects infected with Helicobacter pylori. Gut 31(5): $522-525$

Sobhani I, Lehy T, Laurent-Puig P, Cadiot G, Ruszniewski P, Mignon M (1993) Chronic endogenous hypergastrinaemia in humans: evidence for a mitogenic effect on the colonic mucosa. Gastroenterol 105(1): 22-30

Song I, Brown DR, Wiltshire RN, Gantz I, Trent JM, Yamada T (1993) The human gastrin/cholecystokinin type $\mathrm{B}$ receptor gene: alternative splice donor site in exon 4 generates two variant mRNAs. Proc Nat Acad Sci USA 90(119): 9085-9089

Thorburn CM, Friedman GD, Dickinson CJ, Vogelman JH, Orentreich N, Parsonnet J (1998) Gastrin and colorectal cancer: A prospective study. Gastroenterol 115(2): 275-280

Todisco A, Ramamoorthy S, Witham T, Pausawasdi N, Srinivasan S, Dickinson CJ, Askari FK, Krametter D (2001) Molecular mechanisms for the antiapoptotic action of gastrin. Am J Physiol Gastrointest Liver Physiol 280: G298-G307

Watson SA, Smith AM (2001) Hypergastrinaemia promotes adenoma progression in the APC ${ }^{\mathrm{Min}-1+}$ mouse model of familial adenomatous polyposis. Cancer Res 61: 625-631

Watson SA, Clarke PA, Morris TM, Caplin ME (2000) Antiserum raised against an epitope of the $\mathrm{CCKB} /$ gastrin receptor inhibits hepatic invasion of a human colon tumor. Cancer Res 60(20): 5902-5907

Watson SA, Clarke PA, Smith AM, Varro A, Michaeli D, Grimes S, Caplin M, Hardcastle JD (1998) Expression of CCKB/gastrin receptor isoforms in gastrointestinal tumour cells. Int J Cancer 77: 572 - 577

Watson SA, Durrant LG, Crosbie JD, Morris DL (1989) The in vitro growth response of primary human colorectal and gastric cancer cells to gastrin. Int J Cancer 43(4): 692-696

Watson SA, Michaeli D, Morris TM (1999b) The role of gastrin in the adenoma:carcinoma sequence in the colon. Digestion 60: $\mathrm{O}-25$

Watson SA, Morris TM, Crosbee DM, Hardcastle JD (1993) Hepatic invasive human colorectal xenograft model. Eur J Cancer 29A(12): 1740-1745

Watson SA, Morris TM, Varro A, Michaeli D, Smith AM (1999a) A comparison of the therapeutic effectiveness of gastrin neutralisation in two human gastric cancer models: relation to endocrine and autocrine/paracrine gastrin mediated growth. Gut 45(6): 812-817

Williams AC, Harper SJ, Paraskeva C (1990) Neoplastic transformation of a human colonic epithelial-cell line - in vitro evidence for the adenoma to carcinoma sequence. Cancer Res 50(15): 4724-4730

Winsett OE, Townsend Jr CM, Glass EJ, Thompson JC (1986) Gastrin stimulates growth of colon cancer. Surgery 99(3): 302-307

Wang TC, Dockray GJ (1999) Lessons from genetically engineered animal models. I. Physiological studies with gastrin in transgenic mice. Am J Physiol 277(1Pt1): G6-G11 